\title{
Taking cell cultures to the patient in an attempt to improve chlamydial isolation
}

\author{
Y F NGEOW,* P E MUNDAY, R T EVANS, AND D TAYLOR-ROBINSON \\ From the Division of Communicable Diseases, MRC Clinical Research Centre, Harrow, Middlesex
}

SUMMARY McCoy cell cultures were inoculated with 121 urethral and cervical specimens takerw from patients attending one of two sexually transmitted disease clinics. The mean number ot Chlamydia trachomatis inclusions was greater when the cultures were inoculated with the specimens and centrifuged in the clinic than when the specimens were first stored in liquid nitrogen. Furthermore, 18 of the 29 chlamydia-positive specimens produced larger numbers of inclusions when inoculated immediately. Despite this, the isolation rate from specimens inoculated directly $(22 \%)$ was about the same as from specimens which had been frozen $(21 \%)$. Of the $30^{\circ}$ occasions on which the cell monolayers were disrupted, 29 followed immediate inoculation. Thiș may possibly have been due to some toxic factor in some of the specimens.

\section{Introduction}

The results of various studies indicate that Chlamydia trachomatis organisms are isolated from $40-50 \%$ of men with nongonococcal urethritis and from $20-30 \%$ of women with non-specific genital infections. ${ }^{1}$ These figures are derived from centrifugeassisted isolation of chlamydia in McCoy cells which have been treated in various ways to enhance detection of inclusions and after specimens have been at $4^{\circ} \mathrm{C}$ or room temperature for a few hours or after storage at $-70^{\circ} \mathrm{C}$ or in liquid nitrogen. Some viruses, such as respiratory syncytial virus, are isolated more efficiently by taking susceptible cell cultures to the patient and inoculating the cultures immediately the specimens have been taken. This procedure should provide the maximum opportunity for recovery of most micro-organisms. We therefore inoculated McCoy cell cultures with specimens immediately after obtaining them and centrifuged the cultures in the clinics to determine whether this would enhance the isolation of $C$ trachomatis.

\section{Patients and methods}

STUDY POPULATION

Sixty-two consecutive male patients attending the special clinics at St Mary's Hospital or the Central

*Visiting worker from the Department of Medical Microbiology, Faculty of Medicine, University of Malaya, Kuala Lumpur, Malaysia.

Address for reprints: Dr D Taylor-Robinson, Clinical Research Centre, Watford Road, Harrow, Middlesex HAl 3 UJ

Accepted for publication 17 July 1980
Middlesex Hospital, London, with gonococcal of nongonococcal urethritis and 59 female patients with non-specific genital infections were studied. The investigation formed part of a larger study, for which approval had been obtained from the ethicab committee.

\section{CULTURE TECHNIQUE}

McCoy cells

These were obtained originally from Dr J H Pearc $\overrightarrow{\vec{E}}$ (Microbiology Department, Birmingham University $\bar{\beta}$ and are maintained routinely for no more than 35 passes after removal from storage in liquid nitrogen? Complete medium with antibiotics (CMA) for celle maintenance and the same medium with additiona $\vec{b}$. glucose and serum (CMGA) for chlamydial growt have been described. ${ }^{2}$

\section{Procedure}

Urethral swabs from men and cervical swabs from women were agitated in $0.8 \mathrm{ml}$ of $2 \mathrm{SP}$ medium. Half of this was then stored in liquid nitrogen and the other half was diluted in CMGA medium and putôn directly on a monolayer of McCoy cells on a cover-N slip contained in a plastic flat-bottomed tube. Thesê inoculated cultures were centrifuged in the clinic at $2800 \times g$ for one hour at room temperature in an MSE Super Minor centrifuge. They were then trans $-\frac{0}{7}$ ported to the laboratory and incubated at $37^{\circ} \mathrm{C}$ fors two hours, after which the medium was replaced with $2 \mathrm{ml}$ of CMGA medium containing $1 \mu \mathrm{g} / \mathrm{ml}$ of cycloheximide. After incubation for a further $48 \vec{D}$ hours, the medium was removed and the cells were्ष्त fixed with methanol for 10 minutes, stained with? 
Giemsa, and examined by dark-ground microscopy. ${ }^{2}$ Specimens which had been put in liquid nitrogen were transported to the laboratory in the frozen state and after rapid thawing processed in the same way.

\section{Results}

$C$ trachomatis was isolated from $30.6 \%$ of 62 male urethral and from $16.9 \%$ of 59 cervical specimens. The mean number of inclusions detected in monolayers of cells after immediate inoculation and centrifugation in the clinic was three to four times greater than the mean number detected after storage of an equal portion of the same specimens in liquid nitrogen (table I). Moreover, 18 of the 29 specimens produced a larger number of inclusions after immediate inoculation than after storage. Three specimens produced inclusions after immediate inoculation but not after storage. Two others produced inclusions after storage only, so that the chlamydial isolation rates resulting from use of the two procedures remained similar- $22 \%$ for samples dealt with immediately and $21 \%$ for samples which had been stored.

In the case of the two specimens which produced inclusions after storage unstored aliquots caused complete disintegration of the cell monolayers so that inclusions could not be sought. Indeed, complete or incomplete removal of cells from the coverslips or contamination of the cultures by other microorganisms rendered evaluation impossible with 30 specimens, 29 of which had been inoculated immediately after collection. The occurrence of bacteria and other micro-organisms in these specimens, which may have accounted for the disintegration of the McCoy cell monolayers, is shown in table II. It seems clear that the disruption was not due to overwhelming chlamydial infection because chlamydial inclusions were not detected in cell monolayers which remained intact after they had been inoculated with the frozen portions of the same specimens.

\section{Discussion}

We found that there was no advantage in inoculating cell cultures with specimens immediately they had been obtained in the clinic because it did not enhance the chlamydial isolation rate. This finding differs from that of Reeve et al, ${ }^{4}$ who reported that inoculation of specimens before freezing produced a $20 \%$ higher isolation rate than after freezing and storage. This difference is difficult to reconcile but might be due to the fact that their specimens were frozen at $-70^{\circ} \mathrm{C}$ and possibly incurred a greater chlamydial loss than ours, which were put into liquid nitrogen. Under the right conditions few chlamydial organisms are lost by freezing in liquid nitrogen. ${ }^{5}$ Nonetheless, in the experiment of Reeve et $a l^{4}$ and also in ours, freezing of specimens reduced the number of inclusions which could be detected, so that immediate inoculation might be valuable when a small number of organisms is being sought, for example after antibiotic therapy.

TABLE I Effect of immediate inoculation and of storage on the number of inclusions detected in $C$ trachomatis-positive specimens

\begin{tabular}{|c|c|c|c|c|c|}
\hline & \multirow[b]{2}{*}{$\begin{array}{l}\text { No chlamydia- } \\
\text { positive* }\end{array}$} & \multicolumn{2}{|c|}{ Mean No of inclusions after } & \multicolumn{2}{|l|}{ No of specimens } \\
\hline Specimens & & $\begin{array}{l}\text { Immediate } \\
\text { inoculation }(A)\end{array}$ & Storage (B) & $\begin{array}{l}\text { Producing more } \\
\text { inclusions by } A \\
\text { than after } B\end{array}$ & $\begin{array}{l}\text { Disrupting } \\
\text { cell } \\
\text { monolayerst }\end{array}$ \\
\hline Urethral (men) & 19 & 6851 & 1783 & $\begin{array}{l}13 \text { ( } 9 \text { at least } \\
\text { two-fold }) \neq\end{array}$ & $\begin{array}{l}2 \text { (completely) } \\
2 \text { (partially) }\end{array}$ \\
\hline Cervical (women) & 10 & 20549 & 7452 & $\begin{array}{l}5 \text { ( } 4 \text { at least } \\
\text { two-fold })\end{array}$ & 5 (partially) \\
\hline
\end{tabular}

* includes three specimens in which bacterial contamination made counting inaccurate.

+ Cell monolayer disruption occurred only with specimens inoculated immediately.

\# Three of the 19 specimens produced at least two-fold more inclusions after B than by $\mathbf{A}$.

TABLE II Micro-organisms contaminating McCoy cell monolayers which were disrupted after immediate inoculation of specimens*

\begin{tabular}{|c|c|c|c|c|c|c|}
\hline \multirow{3}{*}{$\begin{array}{l}\text { Disruption of } \\
\text { monolayer }\end{array}$} & \multicolumn{6}{|c|}{ No of specimens containing: } \\
\hline & \multirow[b]{2}{*}{ Bacteria } & \multirow{2}{*}{$\begin{array}{l}\text { Candida } \\
\text { spp }\end{array}$} & \multirow{2}{*}{$\begin{array}{l}\text { Trichomonas } \\
\text { vaginalis }\end{array}$} & \multirow[b]{2}{*}{ No organisms } & \multicolumn{2}{|c|}{ Total } \\
\hline & & & & & No & $\%$ \\
\hline Complete & 8 & 2 & 3 & 7 & 20 & $18 \cdot 2$ \\
\hline Partial & 3 & 3 & 0 & 3 & 9 & $8 \cdot 2$ \\
\hline Total & 11 & 5 & 3 & 10 & 29 & $26 \cdot 4$ \\
\hline
\end{tabular}

*Only one stored specimen, which contained $T$ vaginalis, produced disruption and this was partial. 
However, we found that the disruption of cell monolayers which occurred after immediate inoculation was a problem. It is interesting that freezing of specimens generally destroyed whatever was responsible for the cell disruption. Often there was an obvious microbial contaminant which may have accounted for it, but sometimes no contaminating micro-organism was detected. Furthermore, it was clear that the cell monolayers had not been disrupted by an overwhelming chlamydial infection. In such circumstances, the possibility that the specimens may contain a toxin, in the same way that faecal specimens from patients with pseudo-membranous colitis contain the toxin liberated by Clostridium difficile, ${ }^{6}$ should not be ignored.

We thank Dr G W Csonka, Dr J R W Harris, and Dr Joan Nabarro for allowing us to obtain specimens from their patients.

\section{References}

1. Taylor-Robinson D, Thomas BJ. The role of Chlamydias trachomatis in genital-tract and associated diseases. J Clin Path 1980;33:205-33.

2. Thomas BJ, Evans RT, Hutchinson GR, Taylor-Robinson D? Early detection of chlamydial inclusions combining the use of cycloheximide-treated McCoy cells and immunofluorescence staining. J Clin Microbiol 1977;6:285-92.

3. Darougar S, Kinnison JR, Jones BR. Simplified irradiate McCoy cell culture for isolation of chlamydiae. In: Nichol\$ RL, ed. Trachoma and Related Disorders. Excerpta Medica. Amsterdam, 1971:63-70.

4. Reeve $\mathbf{P}$, Owen J, Oriel JD. Laboratory procedures for the isolation of Chlamydia trachomatis from the human genita 6 tract. J Clin Path 1975; 28:910-4.

5. Prentice MJ, Farrant J. Survival of chlamydiae after cooling to - $196^{\circ}$ C. J Clin Microbiol 1977;6:4-9.

6. Larson HE. Pseudomembranous colitis is an infection. $J$ Infec tion 1979; 1:221-6. 